\title{
EFEKTIVITAS BIMBINGAN BELAJAR DALAM \\ BIMBINGAN DAN KONSELING DI MADRASAH
}

\author{
Alfin Mustikawan \\ Dosen Tetap Jurusan PIPS Fakultas Tarbiyah UIN Maliki Malang
}

\begin{abstract}
This research study was aimed at revealing the effectiveness of the learning guidance services in the guidance and counseling program, particularly: the application, the effectiveness and (4) the problem arising and its causes. This research was a case study. The data were collected through observations, interviews, documentation, and questionnaire. The data were analyzed using the interactive model and the quantitative descriptive technique.

The research findings showed that: (1) the application is effective. As many as $78.78 \%$ respondents said that the work of guiding teachers was effective and $68.99 \%$ respondents said that subject matter teachers were involved in guiding processes. (2) The results of learning guidance services given academic and nonacademic advantages. As many as $71.52 \%$ respondents said that learning guidance services also academic advantages. As many as $86.08 \%$ respondents said that learning guidance services also gave non-academic advantages. (3) The problems faced by counselors in applying learning guidance services include the limited time for them to give advice in the classroom and the lack of counselors. These problems are caused by too many class hours for religion lessons and there is no rule for counselors to get into the classrooms. Keywords:
\end{abstract}

\section{A. Latar Belakang Masalah}

Kurikulum 2006 yang diberlakukan saat ini, tentu saja membawa angin segar bagi kemajuan pendidikan di Indonesia. Guru dituntut untuk lebih terampil dalam menyampaikan suatu metode pengajaran. Siswa tentunya juga tidak ingin ketinggalan, mereka juga harus menguasai berbagai materi yang menuntut kompetensi.

Berkaitan dengan diberlakukannya kurikulum 2006, layanan bimbingan dan konseling juga ikut menyesuaikan dalam membantu kegiatan belajar siswa. Bimbingan dan konseling sebetulnya tidak bisa terlepas dari kegiatan belajar mengajar di sekolah. Melalui bimbingan dan konseling siswa diharapkan dapat mengenal kemampuan belajar yang ia miliki dan bakat yang ada pada dirinya.

Selain hal di atas, ditambah lagi persoalan belajar yang dihadapi oleh siswa sangat beragam sehingga membutuhkan penyelesaian yang beragam pula. Hal ini disebabkan pengetahuan yang masih kurang dari siswa tentang cara belajar yang efektif. Kebanyakan dari mereka masih menganggap bahwa guru adalah pemberi ilmu tunggal atau segalanya yang mengakibatkan mereka sering tergantung pada guru.

Guru bimbingan dan konseling ketika memberikan layanan bimbingan belajar hendaknya melibatkan komponen sekolah yang lain misalnya guru bidang studi dan 
kepala sekolah. Sayangnya yang terjadi saat ini sering salah paham antara guru bimbingan dan konseling dengan guru bidang studi, ada sebagian dari mereka cenderung berjalan sendiri-sendiri. Padahal jika terjadi sebuah kerjasama yang baik tentu bimbingan belajar bagi siswa akan berjalan dengan baik, sehingga prestasi mereka dapat meningkat.

MAN 6 Jombang sebagai sebuah institusi pendidikan yang menghadapi persoalan di atas berusaha untuk memecahkannya. MAN 6 Jombang menyelenggarakan layanan bimbingan dan konseling yang salah satu layanannya adalah bimbingan belajar untuk mengantisipasi persoalan berkaitan dengan peserta didik yang kesulitan dalam belajar sebagai upaya mencapai prestasi belajar yang maksimal.

Pelaksanaan bimbingan belajar di MAN 6 Jombang masih terkesan sebagai sebuah rutinitas dan bukan merupakan kewajiban. Identifikasi terhadap persoalan belajar perlu dilakukan agar bimbingan belajar yang diberikan tepat sasaran. Kinerja guru pembimbing harus lebih ditingkatkan dan keterlibatan guru bidang studi serta pihak lain seperti kepala sekolah dan jajarannya perlu diperhatikan untuk meningkatkan pelaksanaan bimbingan belajar.

Kinerja guru pembimbing dalam pelaksanaan bimbingan belajar juga merupakan faktor pendorong yang sangat baik dalam menunjang keberhasilan siswa. Pelaksanaan bimbingan belajar di MAN 6 Jombang dihadapkan pada banyak kesulitan dan hambatan. Hasil bimbingan belajar saat ini kurang berorientasi pada sisi akademik siswa misalnya meningkatkan kemampuan siswa, motivasi siswa, pemanfaatan sarana belajar dan perubahan pola belajar. Sisi nonakademik juga sering terabaikan dalam hasil bimbingan belajar, dimana guru pembimbing tidak berupaya menumbuhkan motivasi siswa untuk melanjutkan kejenjang yang lebih tinggi.

\section{B. Metode Penelitian}

Penelitian ini merupakan penelitian studi kasus dengan pendekatan kualitatif sebagai pendekatan utama dan di dukung pendekatan kuantitatif. Alasan pemilihan jenis penelitian studi kasus adalah dikarenakan fenomena yang terjadi bersifat kasuistik dan berbeda dengan tempat lain. Peneliti tidak dapat banyak mengontrol peristiwa-peristiwanya dan yang jadi fokus penelitian mengenai gejala nyata saat sekarang, walaupun tidak dapat lepas dari latar belakang masa lalu yang menjadi konteks peristiwa saat ini (Sayekti Pudjosuwarno : 1995 : 1)

Menurut pendapat Wilson (Suharsimi Arikunto, 1995 : 5) "Case study is a process of research which tries to describe and analyze some entity in qualitative, complete and comprehensive terms not infrequently over a period of time." Maksunya adalah studi kasus merupakan penelitian yang menggambarkan dan menganalisis beberapa kasus secara lengkap dan menyeluruh. Dalam penelitian studi kasus ini yang menjadi subjek penelitian adalah guru bimbingan dan konseling dan siswa sebagai narasumber 
utama. Sedangkan subjek yang lain adalah kepala sekolah, guru bidang studi, wali kelas, bagian kurikulum dan bagian kesiswaan.

Penelitian ini bertempat di MAN 6 Jombang. Lincoln dan Guba (Suryati Sidharto, 1995 : 3) menyatakan fenomena sebagai "....time and setting dependent...", artinya waktu dan tempat kasus terjadi saling tergantung.

Teknik pengumpulan data yang digunakan dalam penelitian ini adalah sebagai berikut:

\section{Pengamatan (observation)}

Burhan Bungin (2001:58) berpendapat " Atas dasar interaksinya, orang membedakan antara pengamatan biasa dengan pengamatan terlibat." Pembedaan tersebut didasarkan atas ada atau tidaknya interaksi antara peneliti dengan informan . Pengamatan dalam penelitian ini dilakukan dalam dua bentuk yaitu pengamatan dengan partisipasi dan pengamatan tanpa partisipasi.

\section{Wawancara}

Wawancara merupakan salah satu tehnik pengumpulkan data untuk mendapatkan informasi dengan cara bertanya langsung dengan responden. Menurut Masri Singarimbun (1999 : 192) interview atau wawancara adalah suatu proses tanya jawab antara dua orang atau lebih secara langsung bertatap muka atau melalui media.

3. Analisis Dokumen (dokumentasi)

Menurut Moleong (1995 : 160) analisis dokumentasi digunakan karena merupakan sumber yang stabil, kaya dan mendorong serta dokumentasi bersifat alamiah sesuai dengan konteks lahiriah tersebut. Dalam penelitian ini dokumentasi yang diperlukan adalah sejarah berdirinya sekolah, data siswa yang mengalami masalah belajar, jumlah siswa yang mengikuti bimbingan khususnya layanan bimbingan belajar dan nilai hasil ulangan umum siswa serta dokumen yang berkaitan dengan program bimbingan belajar.

\section{Angket}

Teknik yang digunakan adalah purposive sampling karena sampel yang dipilih telah ditentukan berdasarkan karakteristik tertentu. Mengingat adanya jejang atau stratifikasi pada populasi, maka terpilihlah 158 siswa sebagai sampelnya dari 3 tiga tingkatan kelas. Adapun penyebaranya adalah sebagai berikut kelas X sejumlah 69 siswa, kelas XI 48 siswa dan kelas III 41 siswa.

Keabsahan data dalam penelitian ini di bagi menjadi dua bagian, untuk data kualitatif dilakukan melalui memperpanjang waktu penelitian, trianggulasi data, member cheeking, pilihan informan dan kedudukan peneliti. Untuk data kuantitatif 
dilakukan melalui penghitungan validitas dan reliabilitas angket dan hasil uji coba angket.

Perhitungan validitas menggunakan analisis faktor dan kriteria penetapan batas minimal koefisien reliabilitas yang digunakan dalam penelitian ini adalah mengacu pendapatnya Linn (Djemari Mardapi, 2005: 3) Menyatakan bahwa "Alat ukur dapat dikatakan baik bila memiliki indeks keandalan minimum 0,7." Dengan demikian batas minimal koefisien reliabilitas adalah 0,7.

Variabel pelaksanaan yang mengungkapkan pelaksanaan bimbingan belajar oleh guru bimbingan dan konseling memuat 8 butir. Hasil pengujian terhadap variabel ini menunjukkan angka Kaiser-Meyer-Olkin (KMO) 0,686 dengan probabilitas Uji Barlett 0,000 (lampiran 2). Variabel hasil mengungkapkan hasil pelaksanan bimbingan belajar memuat 9 butir. Hasil pengujian terhadap variabel ini menunjukkan angka KaiserMeyer-Olkin (KMO) 0.771 dengan probabilitas Uji Barlett 0,000 (lampiran 2).

Penghitungan reliabilitas dengan formula Alpha dari Cronbach diperoleh nilai 0,8163 untuk variabel pelaksanaan dan 0,8420 untuk variable hasil (lampiran 2), yang berati lebih dari 0,7, maka angket dapat dikatakan memiliki keterandalan dan dapat digunakan untuk mengumpulkan data.

Menurut Bryman $(2001 ; 264)$ penelitian kualitatif adalah sebuah cara penelitian yang biasanya menekankan pada kata-kata daripada hitungan angka dalam pengumpulan dan analisis data. Analisis data yang meliputi reduksi data, display data dan penyimpulan data. Analisis data menggunakan model yang dikembangkan Miles dan Huberman yaitu analisis interaktif.

Guna menilai data yang diperoleh melalui angket dilakukan dengan melihat tingkat kecenderungan. Adapun kriteria penilaian dalam penelitian ini mengacu pada pendapat Saifuddin Azwar (1998: 163), kriteria tersebut sepenuhnya dapat dilihat pada tabel 4 dibawah ini:

Tabel 1

Kriteria Penilaian

\begin{tabular}{|c|c|c|}
\hline No & Interval Nilai & Kategori \\
\hline 1 & $\mathrm{Mi}+1,5 \mathrm{Sbi}<\mathrm{X}$ & Sangat Baik \\
2 & $\mathrm{Mi}+0,5 \mathrm{Sbi}<\mathrm{X} \leq \mathrm{Mi}+1,5 \mathrm{Sbi}$ & Baik \\
3 & $\mathrm{Mi}-0,5 \mathrm{Sbi}<\mathrm{X} \leq \mathrm{Mi}+0,5 \mathrm{Sbi}$ & Cukup \\
4 & $\mathrm{Mi}-1,5 \mathrm{Sbi}<\mathrm{X} \leq \mathrm{Mi}-0,5 \mathrm{Sbi}$ & Kurang \\
5 & $\mathrm{X} \leq \mathrm{Mi}-1,5 \mathrm{Sbi}$ & Sangat Kurang \\
\hline
\end{tabular}

Keterangan :

X : Skor responden

Mi : Mean ideal

Sbi : Simpangan baku ideal 
Mi $\quad: 1 / 2$ (skor tertinggi ideal + Skor terendah ideal)

Sbi $\quad: 1 / 6$ (skor tertinggi ideal - Skor terendah ideal

Berikut ini kriteria efektivitas untuk data kualitatif :

a. Aspek perencanaan.

1) Terdapat bidang layanan bimbingan belajar

2) Terdapat alat pengumpul data masalah belajar

3) Melibatkan kepala sekolah

4) Melibatkan guru bidang studi

5) Menetapkan metode sarana dan prasana

6) Membuat program kerja

b. Aspek pelaksanaan

1) Masalah belajar yang dihadapi siswa teridentifikasi.

2) Guru pembimbing berperan aktif dalam pelaksanaan bimbingan belajar

3) Guru bidang studi dilibatkan dalam pelaksanaan bimbingan belajar.

4) Sarana dan prasarana bimbingan belajar yang ada dimanfatkan secara optimal.

5) Komponen sekolah dilibatkan.

6) Metode dalam pelaksanaan bimbingan belajar sesuai dengan masalah belajar

7) Waktu pelaksanaan bimbingan yang sesuai jadwal.

c. Aspek hasil.

1) Siswa mulai menyadari atas masalah yang dihadapi.

2) Meningkatnya motivasi siswa dalam belajar.

3) Naiknya nilai siswa pada laporan hasil belajar.

4) Kinerja guru BK yang dirasakan oleh siswa.

5) Kemampuan siswa menghadapi kesulitan belajar secara sendiri.

6) Perubahan pola belajar pada siswa.

7) Siswa mampu menggunaan fasilitas belajar.

8) Siswa termotivasi untuk melanjutkan kejenjang pendidikan yang lebih tinggi.

\section{Hasil dan Pembahasan.}

Layanan bimbingan Bimbingan belajar yang diberikan di MAN 6 Jombang merubapakan bagian darai layanan bimbingan dan konseling. Program bimbingan belajar di MAN 6 Jombang secara langasung termuat dalam program bimbingan dan konseling. Dalam menjalankan layanan bimbingan belajar di MAN 6 Jombang dibagai menjadi 3 hal yaitu:

\section{Pelaksanan Bimbingan Belajar Di MAN 6 Jombang}

a. Identifikasi masalah belajar

Bimbingan belajar di MAN 6 Jombang dilaksanakan secara terpadau sesuai kebutuhan dan program yang telah direncanakan sebelumnya. Sebelum memberikan bimbingan guru pembimbing terlebih dahulu mengidentifikasi persoalan yang 
dihadapi siswa. Di awal masuk siswa diberi angket yang mengungkap tentang berbagai hal termasuk didalamya masalah belajar. Jadi dari angket dipilah mana yang teramsuk masalah belajar, masalah keluarga, masalah dengan teman. Setelah itu dianalisis dan dicarikan solusi. Masalah tersebut satu persatu ditangani oleh guru bimbingan dan konseling .

Selain di atas identifikasi juga dilakukan berdasarkan Nilai Ebtanas Murni (NEM) ketika siswa masuk pertama. Bagi siswa yang memiliki NEM rendah dan masuk kategori cadangan ditangani atau dipantau dengan seksama. Hal ini dikarenakan di MAN 6 Jombang memiliki peraturan bagi siswa cadangan yang tidak naik kelas maka akan di keluarkan. Di samping itu dalam memberikan bimbingan belajar juga berdasar hasil nilai laporan belajar pada semester pertama

b. Kinerja guru pembimbing dalam memberikan bimbingan belajar

Sebagai upaya mengoptimalkan layanan bimbingan belajar guru bimbingan dan konseling di MAN 6 Jombang memiliki moto "Peduli Siswa" artinya guru yang bersifat proaktif agar siswa memanfaatkan layanan bimbingan belajar yang ada. Ditambah lagi program pemangilan siswa sebanyak 2-3 orang setiap hari diharapkan mampu mengetahui berbagasi persoalan yang dihadapi siswa terutama bimbingan belajar.

Gambaran lebih jelas mengenai persentase kinerja guru Bimbingan dan Konseling dalam memberikan layanan bimbingan belajar secara terperinci di MAN 6 Jombang terlihat pada tabel 2 berikut:

Tabel 2

Persentase Efektivitas Kinerja Guru Pembimbing

\begin{tabular}{|c|c|c|}
\hline \multirow{2}{*}{ Kategori } & \multicolumn{2}{|c|}{ Kinerja Guru Bimbingan dan Konseling } \\
\cline { 2 - 3 } & Jumlah & Persen \\
\hline Sangat Baik & 14 & $8,87 \%$ \\
Baik & 36 & $22,78 \%$ \\
Cukup Baik & 66 & $41,78 \%$ \\
Kurang Baik & 36 & $22,78 \%$ \\
Sangat Kurang Baik & 6 & $3,79 \%$ \\
\hline JUMLAH & 158 & $100 \%$ \\
\hline
\end{tabular}

Secara umum dapat ditunjukkan seperti grafik batang berikut:

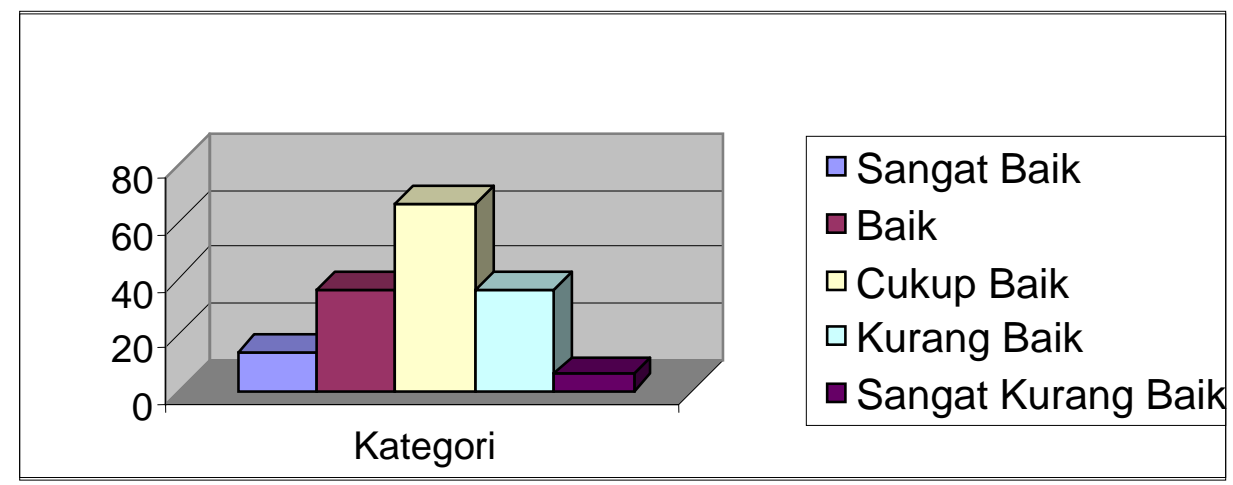


Gambar 2

Grafik Batang Efektivitas Kinerja Guru Pembimbing

c. Keterlibatan guru bidang studi dalam memberikan bimbingan belajar

Pelakasanaan bimbingan belajar tidak mutlak menjadi tugus guru bimbingan konseling. MAN 6 Jombang melibatkan berbagai pihak dalam baik itu pihak dalam (sekolah) pihak luar (lembaga bimbingan belajar). Hal ini ditegaskan oleb bapak SS bahwa di MAN 6 Jombang ada mekanisme pembinaan dan layanan dari guru bidang studi, wali kealas, guru pembimbing dan akhirnya kesiswaan. Kepala sekolah lebih dilibatkan dalam hal persetujuan program dan pelindung dari bimbingan dan konseling secara umum. Sedangkan keterlibatan lembaga bimbingan belajar adalah sebatas menyampaikan kiat-kiat jitu tentang belajar karena anak kadang tidak memahami penjelasan dari guru bimbingan dan konseling jadi pihak sekolah mengakui kelebihan lembaga bimbingan belajar dalam memberikan layanan

Gambaran lebih jelas mengenai persentase keterlibatan guru bidang studi dalam pelaksanan bimbingan belajar dilihat pada table 3:

Tabel 3

Keterlibatan Guru Bidang Studi

\begin{tabular}{|c|c|c|}
\hline \multirow{2}{*}{ Kategori } & \multicolumn{2}{|c|}{ Keterlibatan Guru Bidang Studi } \\
\cline { 2 - 3 } & $\mathrm{F}$ & $\mathrm{P}$ \\
\hline Sangat Terlibat & 21 & $13,29 \%$ \\
Terlibat & 23 & $14,56 \%$ \\
Cukup Terlibat & 65 & $41,14 \%$ \\
Kurang Terlibat & 25 & $15,82 \%$ \\
Tidak Terlibat & 24 & $15,19 \%$ \\
\hline JUMLAH & 158 & $100 \%$ \\
\hline
\end{tabular}

Secara keseluruhan dapat dilihat pada grafik batang berikut:

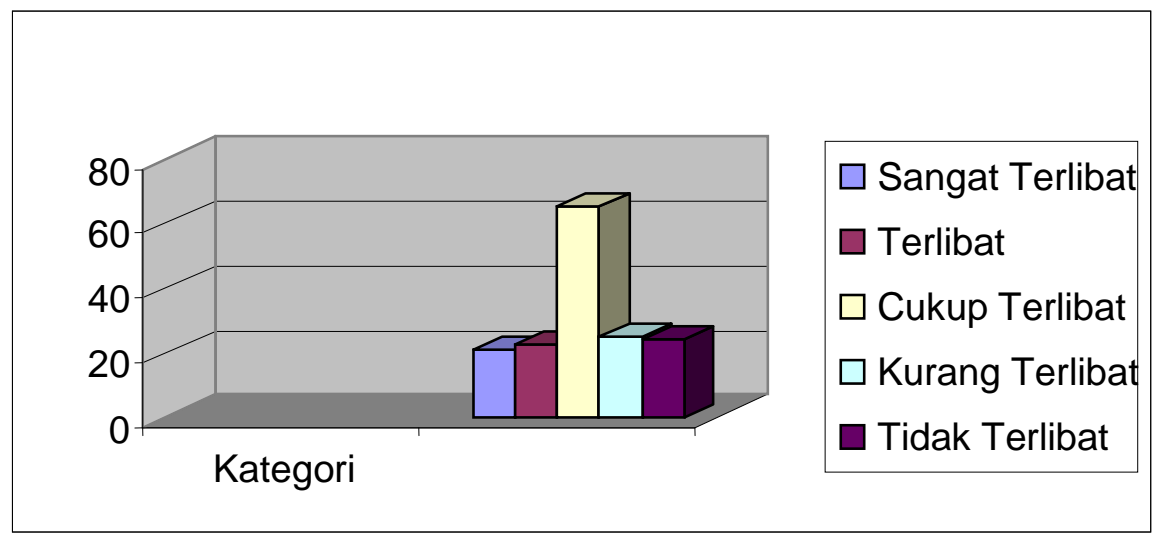

Gambar 3

Grafik Batang Keterlibatan Guru Bidang Studi

\section{Hasil Layanan Bimbingan Belajar}


a. Pengungkapan Hasil Bimbingan belajar

Evaluasi bimbingan belajar dilakukan setiap akhir tahun dan tiap bulan untuk mengetahui hasil bimbingan belajar yang telah dilaksanakan. Menurut koordinator bimbingan dan konseling evaluasi dilakukan akhir tahun dan tiap bulan rapat mengevaluaisi kinerja sebelumnya kalau ada yang kurang bagus segera diperbaiki, dengan harapan ada perbaikan kinerja ke depan Di samping itu juga ada evaluasi tiap sermester sekali, jadi evaluasinya melihat dari hasil rapor, jika anak nilainya dari jelek ke baik maka anak sudah berhasil, tapi jika dari jelek ke jelek maka kami kurang berhasil bimbingan yang diberikan.

Melihat hal diatas perencanan dan pelaksanan bisa dibilang cukup baik tapi masih belum optimal. Hal ini disebabkan masih ada kendala yang dihadapi oleh guru bimbingan dan konseling. Kedala tersebut diantaranya rasio jumlah guru pembimbing dengan siswa dan alokasi waktu yang kurang.

b. Hasil Bimbingan Belajar Secara Akademik

Hasil dari pelaksanan menunjukan adanya layanan bimbingan belajar yang efektif. Layanan ini terjadi di awal kelas satu sebab anak ketikal sudah tahu metode belajar yang baik dan penggunaan waktu luang maka tugas guru bimbingan dan konseling hanya mengawasi dan mengingatkan agar anak itu konsisten dengan waktu. Menurut bapak SS banyak anak yang sudah sampai di sini tidak konsisten dengan waktu belajar karena terpengaruh dengan lingkungan luar yang tidak bisa dikontrol oleh guru bimbingan dan konseling. Jadi layanan bimbingan belajar yang paling efektif itu dikelas satu. Untuk itu siswa kelas $\mathrm{X}$ sudah dibekali dengan cara-cara belajar yang efektif dan efisien waktu masa orientasi.

Gambaran lebih jelas mengenai persentase kecendrungan manfaat akademik bagi siswa dilihat pada tabel 4 berikut:

Tabel 4

Manfaat Akademik Bagi Siswa

\begin{tabular}{|c|c|c|}
\hline \multirow{2}{*}{ Kategori } & \multicolumn{2}{|c|}{ Manfaat akademik bagi siswa } \\
\cline { 2 - 3 } & Jumlah & Persen \\
\hline Sangat Baik & 13 & $8,23 \%$ \\
Baik & 46 & $29,11 \%$ \\
Cukup Baik & 54 & $34,18 \%$ \\
Kurang Baik & 33 & $20,89 \%$ \\
Sangat Kurang Baik & 12 & $7,59 \%$ \\
\hline JUMLAH & 158 & $100 \%$ \\
\hline
\end{tabular}

Secara umum dapat ditunjukkan seperti grafik batang berikut: 


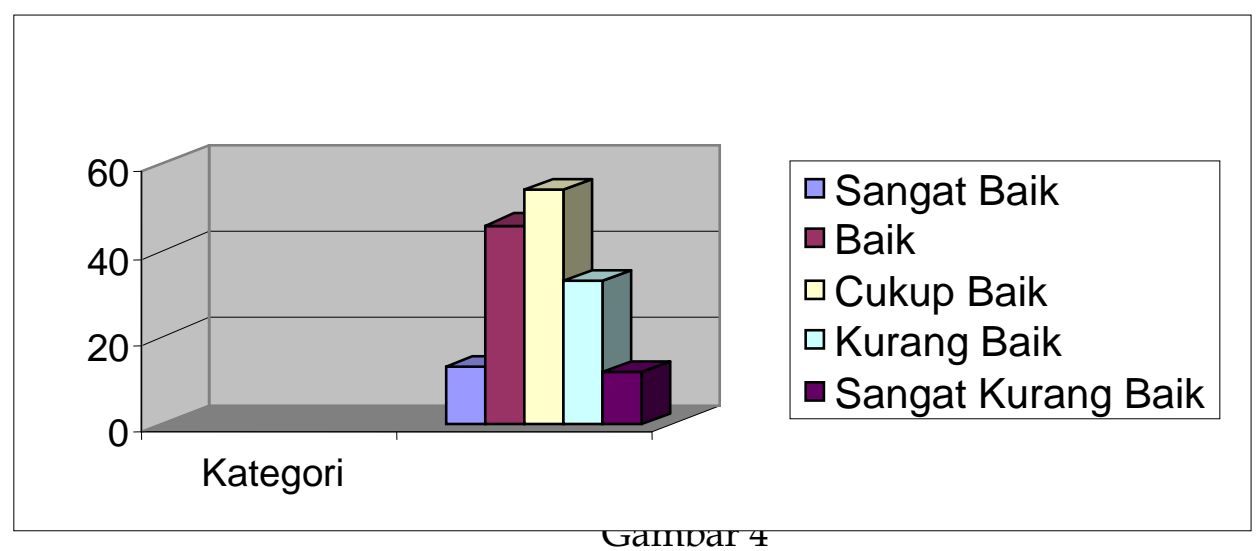

Grafik Batang Manfaat Akademik

\section{c. Hasil Bimbingan Belajar Secara Nonakademik.}

Diakui pula oleh AR bahwa setelah mendapatkan layanan bimbingan belajar maka ia sangat terpacu untuk meraih prestasi yang tinggi karena ia ingin melanjutkan ke perguruan tinggi terutama yang negeri. Hal ini menunjukkan bahwa selain manfaat dlam kegiatan belajar sehari-harai bimbingan belajar yang diberikan juga mampu menumbuhkan motivasi pada siswa untuk melanjutkan kejenjang yang lebih tinggi.

Gambaran lebih jelas dapat dilihat pada table berikut:

Tabel 5

Manfaat Nonakademik Bagi Siswa

\begin{tabular}{|c|c|c|}
\hline \multirow{2}{*}{ Kategori } & \multicolumn{2}{|c|}{ manfaat noakademik bagi siswa } \\
\cline { 2 - 3 } & $\mathrm{F}$ & $\mathrm{P}$ \\
\hline Sangat Tinggi & 46 & $29,11 \%$ \\
Tinggi & 40 & $25,32 \%$ \\
Cukup Tinggi & 50 & $31,65 \%$ \\
Kurang Tinggi & 8 & $5,06 \%$ \\
Tidak Tinggi & 14 & $8,86 \%$ \\
\hline JUMLAH & 158 & $100 \%$ \\
\hline
\end{tabular}

Secara keseluruhan dapat dilihat pada grafik batang berikut:

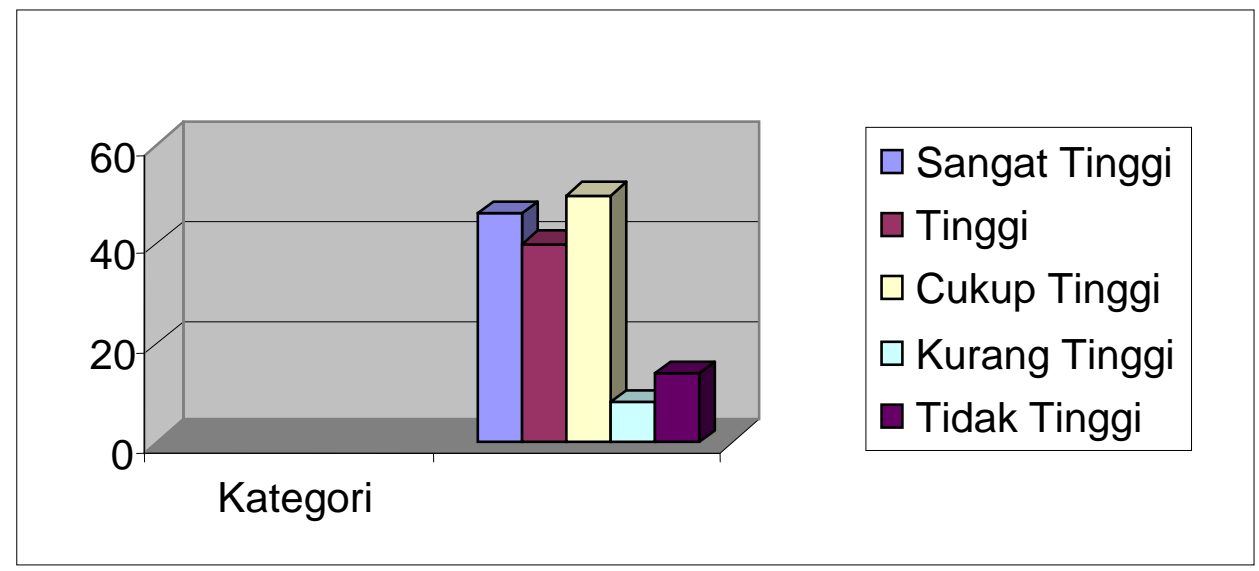

Gambar 5

Grafik Batang Manfaat Non akademik 


\section{Masalah dalam Bimbingan Belajar dan Faktor Penyebabnya.}

a. Alokasi waktu

Persoalan alokasi waktu merubapakan permasalahan yang dirasakan oleh seluruh komponen dari guru pembimbing, siswa, guru bidang studi, walikelas bahkan kepala sekolah. Ketiadaan jam masuk kelas sangat dirasakan oleh guru bimbingan dan konseling, menurut bapak SS karena tidak diberi jam masuk maka waktu tahun ajaran baru anak-anak kelas satu yang sedang mengalami masa orientasi siswa baru dimanfaatkan oleh guru bimbingan dan konseling sebaik mungkin. Guru bimbingan dan konseling semuanya masuk kelas diantaranya memberi materi tentang cara belajar efektif termasuk juga pengaturan atau pemanfaatan waktu jadi cara mengastur wajktu itu supaya diatur dengan baik. Kemudian untuk kelas 2 dan 3 karena tidak ada jam kelas secara terjadwal maka ada kendala.

b. Rasio jumlah guru pembimbing dengan siswa

Masalah lain yang dihadapi saat ini bagi bimbingan dan konseling di MAN 6 Jombang adalah rasio jumlah guru dengan siswa atau dengan kata lain kekurangan jumlah guru. Diakui oleh bapak SS bahwa sebenarnya rasio guru bimbingan dan konseling yang ideal itu 1:150 tapi di sini cukup melebihi. Karena yang terjadi di MAN 6 Jombang adalah 1:192 bahkan ada yang 1:253. Sehinga akhirnya jam kerjanya 6 hari kerja dari pagi sampai siang tidak ada liburnya seperti guru yang lain. Dengan 6 hari kerja mungkin dari sekolah sudah dipandang cukup menutupi kekuranagn guru bimbingan dan konseling. Padahal menurut bapak SS di MAN 6 Jombang masih kurang guru bimbingan dan konseling minimal 1 lagi. Karena permasalahan anakanak di MAN 6 Jombang cukup kompleks disebabkan perbedaan latar belakang kulktur, ekonomi, dan pendidikan.

\section{Kesimpulan}

Berdasarkan hasil pembahasan dapat ditarik kesimpulan sebagai berikut:

\section{Pelaksanaan Bimbingan Belajar}

a. Pelaksanaan bimbingan belajar di MAN 6 Jombang dibagi menjadi mulai dengan identifikasi persoalan belajar yang dihadapi yang siswa yang dilakukan secara efektif ketika siswa baru masuk dan melalui hasil belajar siswa.

b. Semua guru pembimbing berperan aktif dalam memberikan layanan. Berdasarkan angket yang disebarkan menunjukkan bahwa sebanyak $70,78 \%$ responden menyatakan bahwa kinerja dari guru pembimbing sudah efektif dan hanya sekitar 3,79\% yang menyatakan sangat kurang (tidak efektif). 
c. Keterlibatan guru bidang studi dalam proses bimbingan yang dilakukan adalah sebagai sumber informasi tentang siswa dan pelaksana bimbingan belajar dikelas. Untuk keterlibatan guru bidang studi menunjukkan bahwa 68,99\% responden menyatakan bahwa guru bidang studi sudah terlibat dalam proses bimbingan belajar.

\section{Hasil Bimbingan Belajar}

a. Pengungkapan hasil bimbingan belajar dilakukan melalui evaluasi terhadap pelaksanaan bimbingan belajar dilakukan setiap akhir tahun dan tiap bulan diadakan rapat untuk mengevaluasi guna mengetahui hasil yang telah dicapai.

b. Hasil secara akademik bagi siswa terlihat dari manfaat bimbingan belajar diantranya, meningkatnya motivasi siswa dalam belajar, kemampuan siswa menghadapi kesulitan belajar secara sendiri, perubahan pola belajar pada siswa dan siswa mampu menggunaan fasilitas belajar. Berdasarkan angket yang disebarkan menunjukkan bahwa sebanyak $71,52 \%$ responden menyatakan bimbingan belajar memberikan manfaat akedemik.

c. Hasil nonakademik dari bimbingan belajar ditunjukkan oleh meningkatnya motivasi siswa untuk melanjutkan kejenjang pendidikan yang lebih tinggi. Berdasarkan angket yang disebarkan menunjukkan bahwa sebanyak 86,08\% responden menyatakan bimbingan belajar memberikan manfaat nonakedemik.

3. Masalah dalam Layanan Bimbingan Belajar dan Faktor Penyebabnya.

a. Masalah dalam bimbingan belajar yang dihadapi

1) Alokasi waktu yaitu ketiadaan jam masuk kelas sehingga guru pembimbing kesulitan dalam memberikan materi bimbingan belajar.

2) Rasio guru dan siswa yang terlalu besar rata-rata 1: 200 padahal idealnya 1:150.

b. Faktor penyebab munculnya masalah

1) Banyaknya jam pelajaran agama sehingga bimbingan dan konseling tidak diberi jam masuk kelas.

2) Minimnya jumlah guru pembimbing yang hanya berjumlah 5 orang, sedangkan siswa yang harus ditangani sebanyak 1269.

\section{E. DAFTAR PUSTAKA}

Bryman, A. (2001). Social methode. New York: Oxford University Press Inc.

Burhan Bungin. (2001). Metode penelitiaan kualitatif. Jakarta: PT. Raja Grafindo Persada.

Djemari Mardapi. (2005). Kumpulan makalah seminar dan lokakarya. Yogyakarta: Program Pascasarjana Universitas Negeri Yogyakarta.

Masri Singarimbun \& Sofyan Effendi (1995). Metode penelitian survey. Jakarta: LP3ES. 
Miles, B. M., \& Huberman, A.M. (1984). Qualitative data analysis. California : Beverly hills.

Moleong, L. J. (1995). Metode penelitian kualitatif. Bandung: Remaja Rosda Karya.

Saifuddin Azwar. (1998). Tes prestasi: Fungsi dan pengembangan pengukuran prestasi belajar. Yogyakarta: Pustaka Pelajar Offset.

Sayekti Pudjosuwarno (1995). Penyusunan proposal studi kasus. Makalah di sajikan dalam penataran metodologi penelitian studi kasus di lembaga penelitian IKIP Yogyakarta.

Suryati Sidharto (1995). Pendekatan naturalistik dalam studi kasus. Makalah di sajikan dalam penataran metodologi penelitian studi kasus di lembaga penelitian IKIP Yogyakarta.

Suharsimi Arikunto. (1995). Kajian lapangan II. Makalah di sajikan dalam penataran metodologi penelitian studi kasus di lembaga penelitian IKIP Yogyakarta. 